\title{
Post Oil Spill Petroleum Hydrocarbon Components Transport and Evaluation in Parts of the Niger Delta Mangrove Swamp of Nigeria: A Case of Hydrocarbon Component Transport through Non-Turbulent Water
}

\author{
T. Odisu ${ }^{1 *}$, C. O. Okieimen ${ }^{2}$, S. E. Ogbeide ${ }^{2}$
}

\begin{abstract}
${ }^{1}$ Department of Chemical Engineering, Federal University of Petroleum Resources, Effurun, NIGERIA
${ }^{2}$ Department of Chemical Engineering, University of Benin, Benin-City, NIGERIA

*Corresponding Author: teddyodi2002@yahoo.com
\end{abstract}

Citation: Odisu, T., Okieimen, C. O. and Ogbeide, S. E. (2021). Post Oil Spill Petroleum Hydrocarbon Components Transport and Evaluation in Parts of the Niger Delta Mangrove Swamp of Nigeria: A Case of Hydrocarbon Component Transport through Non-Turbulent Water. European Journal of Sustainable Development Research, 5(1), em0152. https://doi.org/10.21601/ejosdr/9708

\section{ARTICLE INFO \\ Received: 13 Dec. 2019}

Accepted: 4 Mar. 2020

\begin{abstract}
Parts of the Nigerian Niger Delta which also accommodates huge number of oil facilities has swamps in some parts with non - turbulent water bodies. These water bodies are negatively impacted from oil pollution but lack the capacities to self-clean like high flowing waters. The calm nature of these swamps result in higher than normal retention, partitioning and diffusion of hydrocarbon components. This study investigated aliphatic and aromatic hydrocarbon concentrations at different depths for a period of ten months by simulating an oil spill site ( $8 \mathrm{~m}$ by $5 \mathrm{~m}$ and $1.5 \mathrm{~m}$ deep) typical of a non-turbulent mangrove swamp with suspended sediments and vegetation polluted with 60 litres of crude oil. Impacted water samples were collected at depths of $0.25 \mathrm{~m}, 0.5 \mathrm{~m}, 0.75 \mathrm{~m}$ and $1.0 \mathrm{~m}$. They were filtered and the petroleum aliphatic and aromatic contents analyzed using a GC-FID. The results obtained showed that petroleum hydrocarbons can dissolve and diffuse to different depths at concentrations above safe limits, thus posing great danger to aquatic life and its entire value chain.
\end{abstract}

Keywords: crude oil, hydrocarbons, mangrove -swamp, spill, static- water

\section{INTRODUCTION}

Oil spill cases in the Niger Delta region of Nigeria have become common as a result of oil production activities as well as oil related illegal activities like tapping of oil bearing pipelines, theft and illegal refining. These illegal activities have gradually snow-balled into a seemingly normal phenomenon because of its regular occurrence and poor attention by Government and oil facilities operators. It has now become so common that there is hardly any oil producing part of the oil-rich Niger Delta region of Nigeria that does not have an oil impacted site yet to be attended to - from land to swamp (Adebanwi, 2001; Egberongbe et al., 2006). According to the Department of Petroleum Resources (DPR), between 1976 and 1996 a total of 4,647 incidents resulted in the spill of approximately 2,369,470 barrels of oil into the environment. Of this quantity, an estimated 1,820,410.5 barrels (77\%) were lost to the environment. Only a total of 549,060 barrels of oil representing $23.17 \%$ of the total oil spilled into the environment was recovered (Badejo and Nwilo, 2005). Prince Emeka Ndimele (2018) also reported that between 2006 and
2015 , there is a record of about 5,000 spill sites and 9,343 cases of crude oil spillage leading to the release of huge volume of crude oil into land, swamps, estuaries and coastal waters of Nigeria. Although rampart, the consequences of allowing oil to impact on the environment is too grave to be overlooked.

The problem of oil spill is not limited to the Niger Delta region of Nigeria because over the years, there have been reports of huge volumes of oil spilled into land and water around the globe leaving behind huge negative consequences. However, most reported oil spills have been in high flowing water bodies like rivers and seas. Consequently, in a bid to develop workable template for effective management of oil spills, there have been in-depth reviews of the transport mechanisms as well as concerted efforts in the development of predictive mathematical models to help in understanding and thus proffering solutions to these oil spill cases. The reviews and reports from available literatures have shown that more work have been done on turbulent water bodies than water bodies that are relatively static and laden with huge amount of suspended sediments arising from dead and decaying vegetation as can be found in a mangrove swamp. 


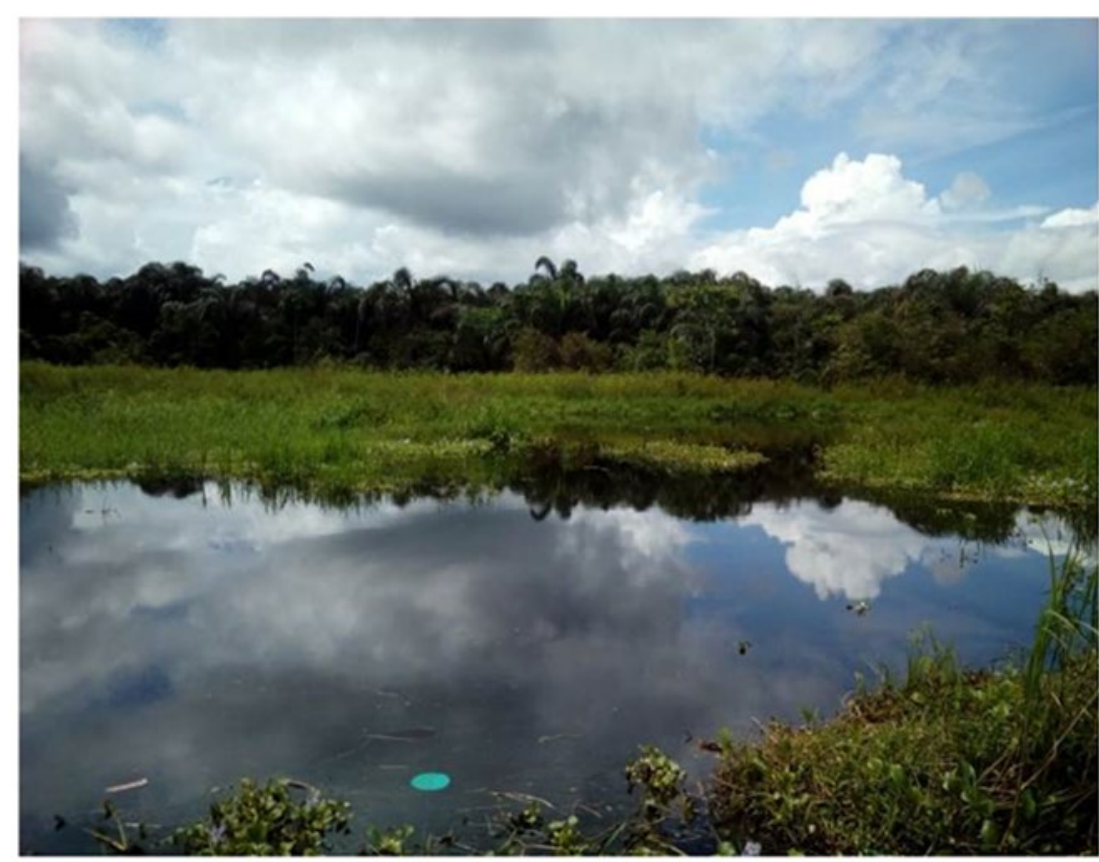

Figure 1. Mangrove swamp with non- flowing water in Warri, Delta state

Researchers who have worked on oil spill cases of turbulent water bodies have concluded that the action of wave in a marine oil spill can break up the surface slick of spilled oil into micron-sized oil droplets. If the water column has a high load of sediment or suspended sediments and particles, they can interact with oil droplets to form oil-mineral -aggregates (OMA). This natural process could stabilize dispersed oil droplets in the water column and enhances their biodegradation rate and lead to self- cleansing (Bragg and Owen, 1995; Le Floch et al., 2002; Owens and Lee, 2003; Owens et al., 2003; Page et al., 2000).

But the case of the mangrove swamps found in parts of the Nigerian Niger Delta region which spans about $70,000 \mathrm{~km}^{2}$ and enjoys the status of one of the ten (10) most important and productive wetland and marine ecosystems in the world because of its huge biodiversity that is completely different.

Mangroves grow in low depositional area which also tends to be sites where oil accumulates. They usually develop in calm, accretive shores where removal of pollutants can be extremely difficult (Gundlach, 1987).

The Nigerian Niger Delta mangrove swamps and marshes comprises of parts that are characterized by very low current or energy (and in some areas, the water may be relatively static), with high sediment load and heavily polluted. For example, in Warri, Sapele and other adjourning villages of Delta State located in the South, we find areas which consist of marshes and mangrove with calm water (see Figure 1). This though does not preclude the presence of high flowing water with tides in some parts as obtained in river Ethiope and areas deep down and close to the sea in other areas. In areas where the water is calm, the residence time of eventually spilled oil may be very high thus making the transport pattern to be based on partitioning instead of particulate as obtained in high flowing waters where the oil slick can be broken into particles as occasioned by bulk velocity. The high retention time allows for gradual dissolution and diffusion of water soluble petroleum hydrocarbon components vertically and into the water column; a phenomenon which should make hydrocarbon recovery extremely difficult in time of clean ups. On the other hand, it is believed that seas and high flowing rivers have selfcleansing capabilities.

Unfortunately though, less attention has been received in terms of research leading to availability of reliable scientific data that could aid adequate oil transport forecasting and spill management in such areas of the Niger Delta. Therefore, there is the need to investigate the transport and residency behavior of spilled crude oil and components for adequate oil spill response and contingency arrangement in calm water regions. The comprehensive review by Imanian et al. (2017), who carried out a review of numerical oil dispersion models and experimental oil spill studies, identified several knowledge gaps and areas that require further investigation. Future research directions and recommendations proposed in their work include in-depth assessment of vertical oil dispersion in the marine environment. In their words, "major areas of future study should focus on gradients of oil concentration by depth in the water column instead of overall penetrated oil mass in a water body; and the application of physically-based formulations rather than empirical oil concentration relationships. Therefore, this study seeks to determine between particulate and partitioning, which best explains oil spill transport in these parts Niger Delta swamp, the degree of oil-component transport and subsequent retention. To achieve this, an oil spill site with the characteristics of a mangrove swamp with non-flowing water was simulated. Water samples were collected in every 30 days interval from different depths and laboratory analysis carried out on the different samples.

The significance of this work is that it has shown the difference in the transport and residency pattern between oil spilled in calm, relatively static swamp water and that in a highly turbulent seas and high flowing rivers. It has also revealed that for every day after a spill, the damage to a nonflowing aquatic ecosystem and its entire value chain could take 


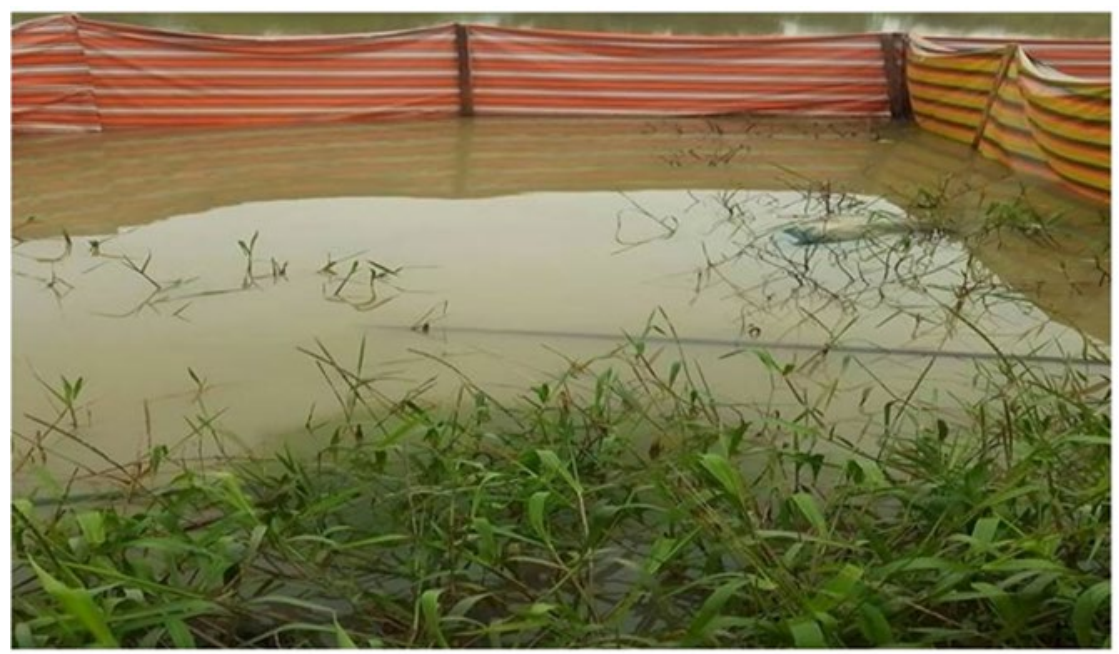

Figure 2. Simulated oil spill site before and after pollution

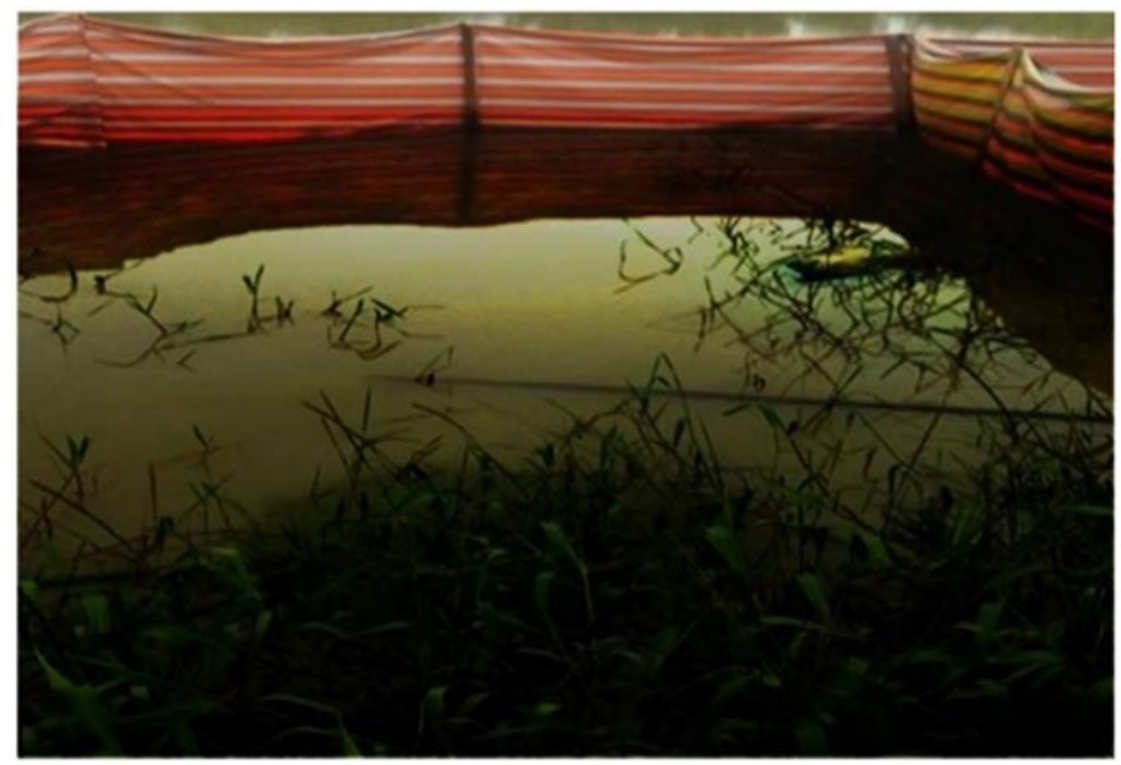

Figure 3. Simulated oil spill site before and after pollution

years to correct even after oil clean-up has been carried out on the water surface.

\section{MATERIALS AND METHODS}

\section{Spill Site Preparation}

The spill site was simulated in Ugbomoro, near Warri by securing an area ( $8 \mathrm{~m}$ long, $5 \mathrm{~m}$ wide and $1.5 \mathrm{~m}$ deep) containing water, shaded with mangrove trees, with high suspended sediment load from decaying organic matter and life vegetation (Figure 2). This site is typical of parts of Nigerian Niger Delta swam because of its non- flowing nature, presence of suspended sediments and vegetation in and around the water body. 60 liters crude oil obtained from a flow station near Warri was then spilled on it to pollute the site (Figure 3). This volume was used to ensure that the sleek covers the entire surface with a height of between $0.1-0.2 \mathrm{~cm}$.

\section{Sample Collection}

Water and sediment samples collection was with the aid of an improvised water depth sampler (Figure 4). The sampler has a pole as its stem and support, a sampling cup with a firm lid, a spring connecting the lid to its base and a line (trigger) connecting the lid to the head of the pole along a calibrated wooden frame. It is lowered into the water and with a firm grip on the line it is pulled upward once we reach the desired depth until the sufficient amount of water has entered the sampling can. The trigger was then released to seal the sampler which is pulled out. The sample was then taken for storage (refrigerator) and petroleum hydrocarbon analysis using a GCFID (gas chromatography with flame ionization detector). The samples were collected once every 30 days at depths of $0.25 \mathrm{~m}$, $0.5 \mathrm{~m}, 0,75 \mathrm{~m}$ and $1.0 \mathrm{~m}$. On collecting each of the samples, they were stored in a refrigerator for a couple of days and analyzed before the next sampling date. This was done so as to ensure that samples taken are sufficiently fresh as at the time of analysis.

\section{Analysis of Samples}

The analytical procedure used in this work for the determination of the extractable total petroleum aliphatic hydrocarbon (ETPALH) and extractable total aromatic 


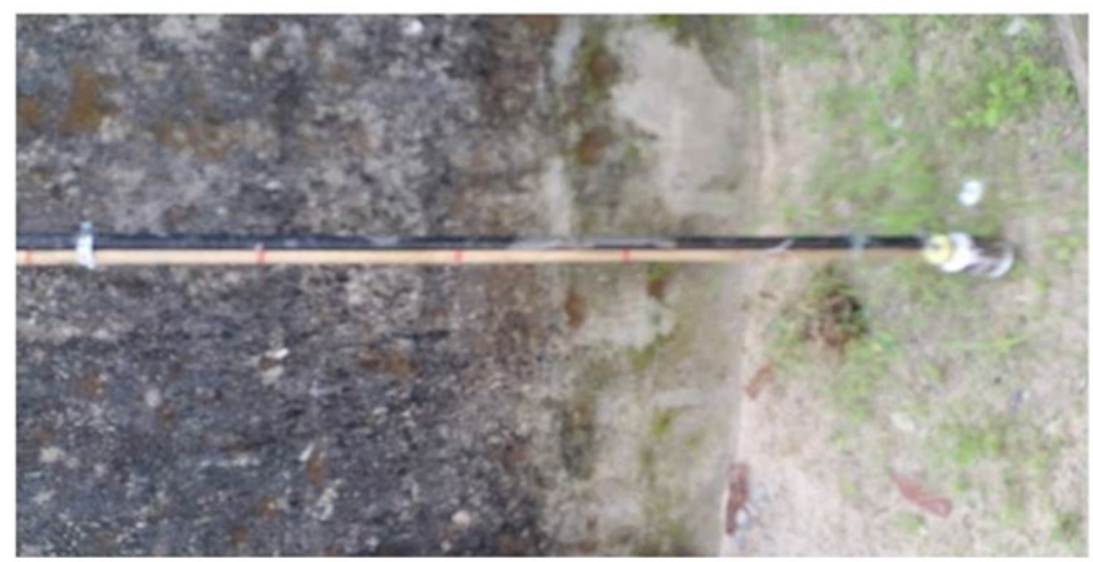

Figure 4. Improvised water depth sampler

hydrocarbon (ETPARH) is in line with that of the American Society for Testing and Materials (ASTM) Method D 3328-78 (American Society for Testing and Materials (ASTM), 1982) and Method 8270 of the US Environmental Protection Agency (EPA) (US Environmental Protection Agency, 2004).

Water samples collected were separated into sediments and water fractions by filtration. $200 \mathrm{ml}$ of water fraction samples for ETPALH analysis was measured using a $250 \mathrm{ml}$ volumetric beaker (Pyrex) and transferred to a 2-liter separating funnel. $30 \mathrm{ml}$ dichloromethane (DCM) (all chemicals were obtained from local chemical vendor in Warri who imports laboratory chemicals from Europe) was then added to the sample in the separating funnel (Pyrex). The separating funnel was then sealed and shaken vigorously for at least three (3) minutes with periodic venting to release excess pressure. The organic layer observed was then allowed to separate from the water phase for a minimum of 5 minutes. The solvent extract was collected in an Erlenmeyer flask. A rotary evaporator (ST 15 OSA, serial no RE 1916) apparatus along with hot water bath $\left(80-90^{\circ} \mathrm{C}\right)$ was assembled such that the concentrator tube was partially immersed in the hot water and the entire lower rounded surface of the flask bathed with hot vapor. The vertical position of the apparatus and the water temperature were adjusted to complete the concentration in 10 minutes.

The extraction was repeated two more times using additional $30 \mathrm{ml}$ portions of solvent. The three solvent extracts were then combined in a 250-ml Erlenmeyer flask and then dried over sodium sulfate thereafter solvent exchanged into hexane, and then concentrated using the rotary evaporator. The extract was then dried by passing it through a column housed by a syringe containing anhydrous sodium sulfate, silica gel and glass wool. Then, DCM was exchanged with hexane by adding $50 \mathrm{ml}$ of hexane to the concentrate and the aliphatic extract collected over the column was concentrated to less than $10 \mathrm{ml}$. The $10-\mathrm{ml}$ concentrate was then placed onto an air blow-down apparatus where the extract volume was further reduced to $1 \mathrm{ml}$ under a gentle stream of air. This was repeated for the extraction of ETPALH of the sediment fraction. The same procedure was followed for the extraction of the ETPARH but for the use of DCM in place of hexane for both the water and sediment fractions. The extracts (ETPALP and ETPARH) from both water and sediment were then analyzed using a GC-FID ((HP 5890 series II) in a laboratory in Warri.

\section{RESULTS AND DISCUSSION}

The study targets monitoring and evaluation of the transport of dissolved petroleum hydrocarbon by diffusion down a water column in line with the experimental procedure outlined above. To achieve the set- out aim, the samples were taken at different depth $(0.25 \mathrm{~m}, 0.5 \mathrm{~m}, 0.75 \mathrm{~m}$ and 1.0$)$ and at time interval of one month for a total duration of ten months. Figures 5 to 6 highlight the transport of aliphatic hydrocarbons by diffusion through the water column.

Figures 5-6 show that the aliphatic hydrocarbon concentration distribution from the first to the tenth month of spill maintained a steady build up at depths of $0.25 \mathrm{~m}$ to $1.0 \mathrm{~m}$. The supply of aliphatic hydrocarbon as a result of dissolution from the bulk of the spill (source) across the interface (multiphase transport) did not constitute a challenge or limit the transport process as there was steady build-up of aliphatic hydrocarbon across the interface to the $0.25 \mathrm{~m}$ region. This suggests that in the absence of turbulence, the possibility of relatively smooth aliphatic hydrocarbon dissolution into water could be high, thus possibly creating a platform for subsequent diffusive transport. Also, considering the dissolution rate for aliphatic hydrocarbon, it suggests that the hydrophobicity of aliphatics could be lower than reported particularly for fresh water. This position is supported by the report of Larche and Petersen (1995) and Brewer et al. (2013) on the effect of salt on the solubility of organic compounds in sea water. Wen-Hui Xie et al. (1997) stated that the presence of electrolytes modifies the solubility of organic compounds in water and concluded that the hydrophobicity could be increased by a factor of 1.36 . This means that the solubility could be reduced by the stated factor for salt water when compared with fresh water. From Figures 5 and 6 and at depth $0.25 \mathrm{~m}$, from first to tenth month, we have $355.758 \mu \mathrm{g} / \mathrm{l}, 870.250 \mu \mathrm{g} / \mathrm{l}, 976.351 \mu \mathrm{g} / \mathrm{l}, 1168.450 \mu \mathrm{g} / \mathrm{l}$, $1505.365 \mu \mathrm{g} / \mathrm{l}, \quad 1737.565 \mu \mathrm{g} / \mathrm{l}, \quad 1927.250 \mu \mathrm{g} / \mathrm{l}, \quad 2437.970 \mu \mathrm{g} / \mathrm{l}$, $2461.620 \mu \mathrm{g} / \mathrm{l}$ and $2462.690 \mu \mathrm{g} / \mathrm{l}$. It can also be seen that while the rate of dissolution for the first seven months seem high, it became sluggish thereafter (months $8-10$ ). This could be as a result of relative saturation of the $0.25 \mathrm{~m}$ strata possibly arising from a dynamic equilibrium between the rate of dissolution 


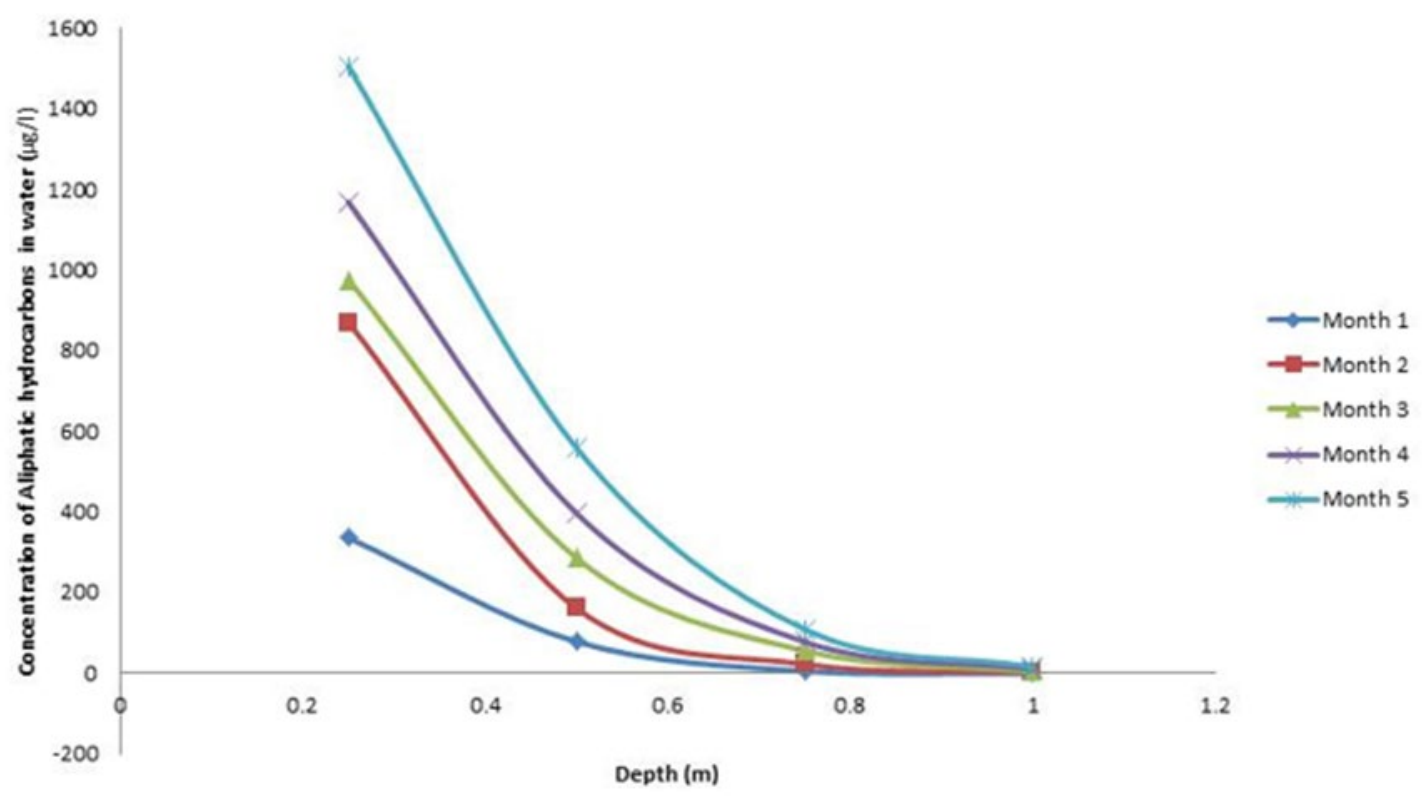

Figure 5. Concentration of aliphatic hydrocarbons versus depth in water for month 1-5

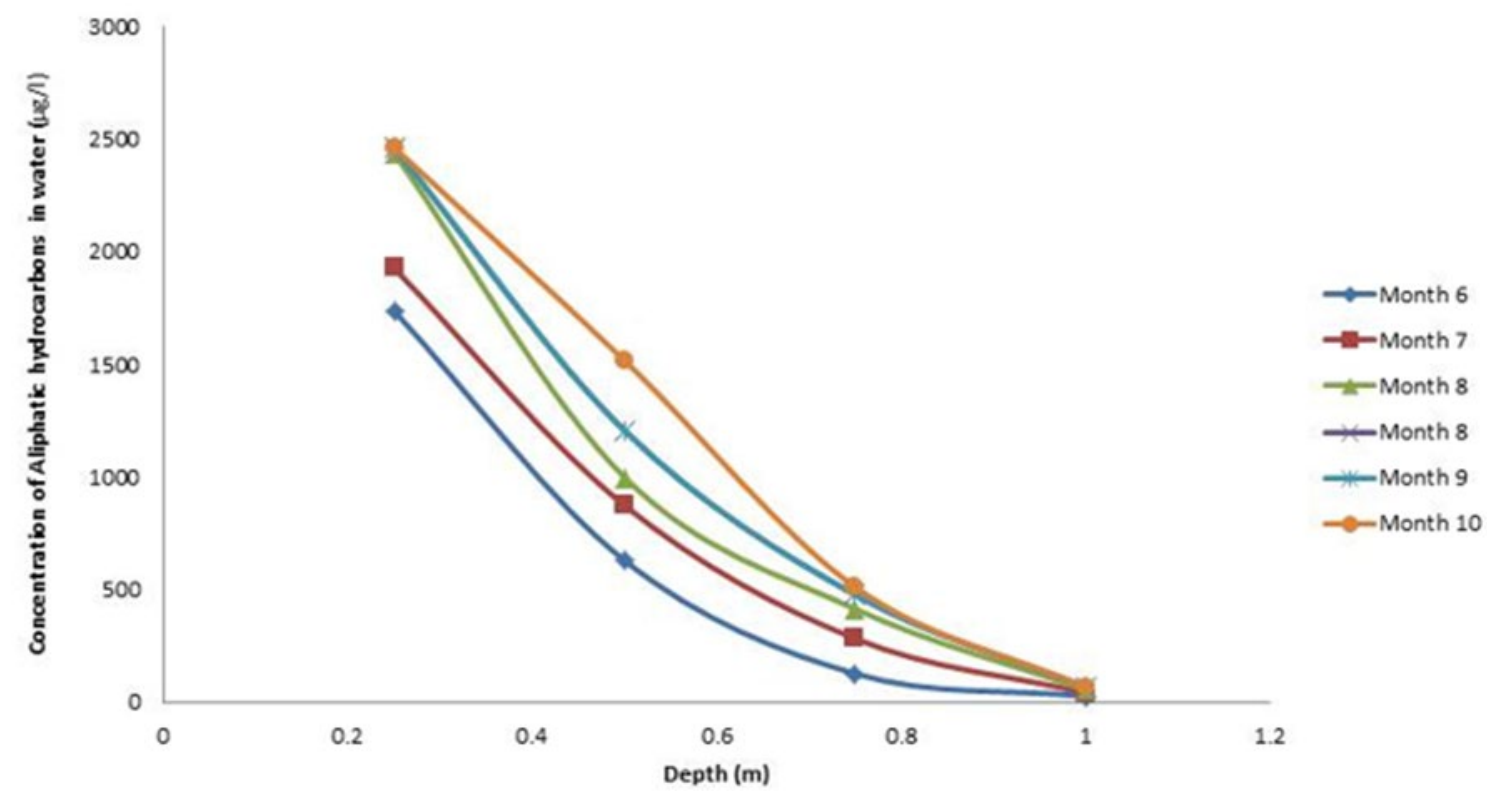

Figure 6. Concentration of aliphatic hydrocarbons versus depth in water for month 6-10

from the bulk into the $0.25 \mathrm{~m}$ strata and the rate of diffusion from the $0.25 \mathrm{~m}$ strata down the water column.

At subsequent depth from $0.5 \mathrm{~m}$ to $1.0 \mathrm{~m}$, it is believed that the transport down the water column is purely diffusive mass transfer with no significant contribution from convection or bulk transport even if total mass flux is the summation of the convective and diffusive mass flux.

The results also show that from depth to depth of every month across the water column, there is a slow build-up of aliphatics down the water column. While in the first month we had $355.758 \mu \mathrm{g} / \mathrm{l}, 78.051 \mu \mathrm{g} / \mathrm{l}, 5.030 \mu \mathrm{g} /$ and $0.006 \mu \mathrm{g} / \mathrm{l}$ recorded at depth of $0.25 \mathrm{~m}, 0.5 \mathrm{~m}, 0.75$ and $1.0 \mathrm{~m}$ respectively, in the second month, $870.255 \mu \mathrm{g} / \mathrm{l}$ was recorded for $0.25 \mathrm{~m}$; while $160.672 \mu \mathrm{g} / \mathrm{l}, 22.450 \mu \mathrm{g} / \mathrm{l}$ and $1.085 \mu \mathrm{g} / \mathrm{l}$ were recorded for $0.5 \mathrm{~m}$, $0.75 \mathrm{~m}$ and $1.0 \mathrm{~m}$ respectively. These values suggest that though aliphatic hydrocarbons as individual or pseudo components are hydrophobic (Brewer et al., 2013; Massachusetts Department of Environmental Protection (MADEP), 2002b), they can diffuse through fresh water column and down the depth to the bed with time. It is worthy of note that the relative availability of the aliphatics may also have contributed to their presence at different strata of the water. The results also suggest that the relative solubility for fresh water will produce over time concentrations far higher that permissible limit of $0.01 \mu \mathrm{g} / \mathrm{l}$ for total aliphatics.

Figures 7-8 highlight the transport of aromatic hydrocarbon by diffusive transport through the water column in the absence of bulk flow.

As highlighted for aliphatic hydrocarbon transport earlier, Figures 7-8 show that the dissolution of aromatics from the bulk did not limit the transport process as the result shows a relatively smooth dissolution process evident in a steady and 


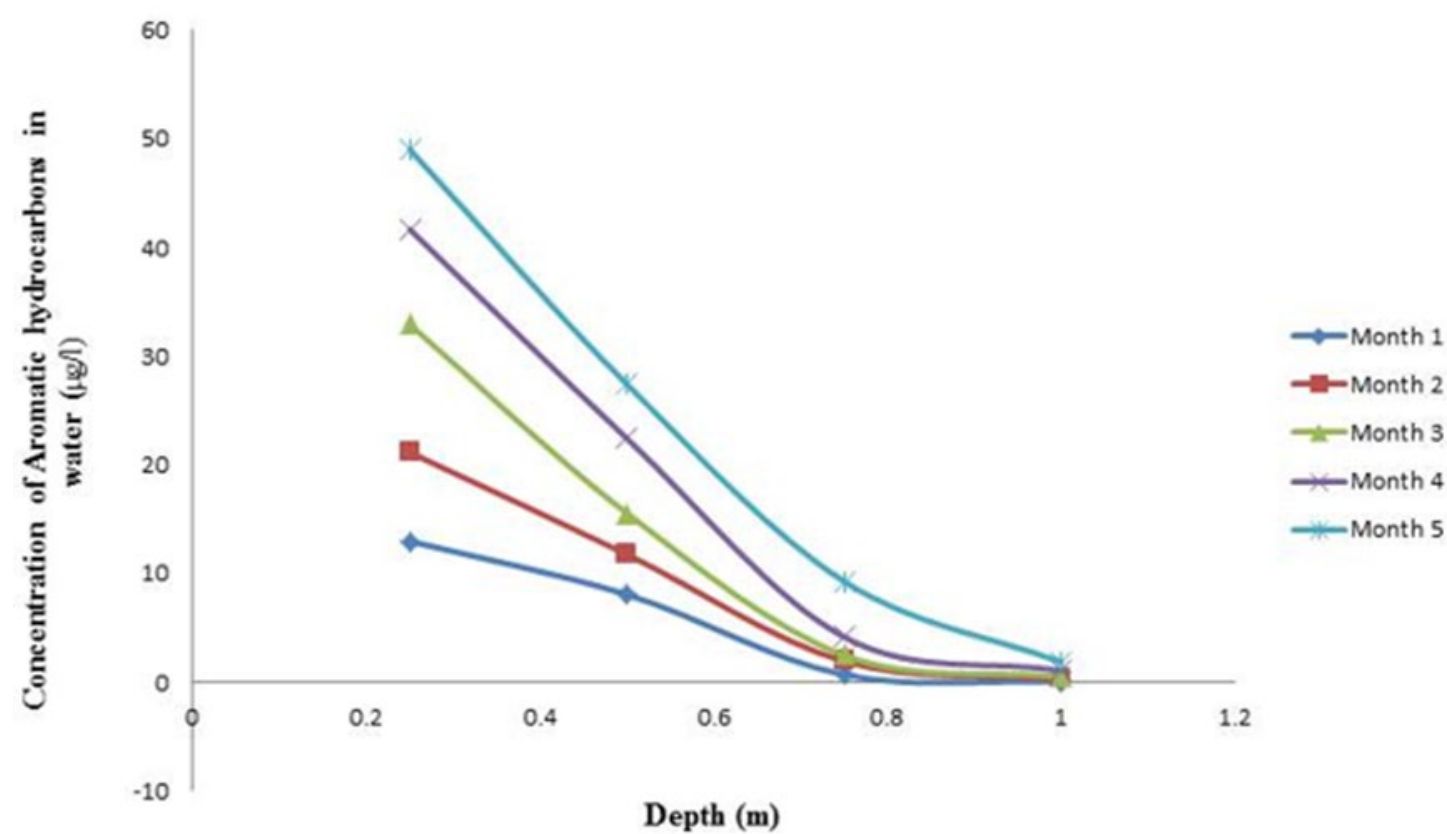

Figure 7. Concentration of aromatic hydrocarbons versus depth in water for month 1-5

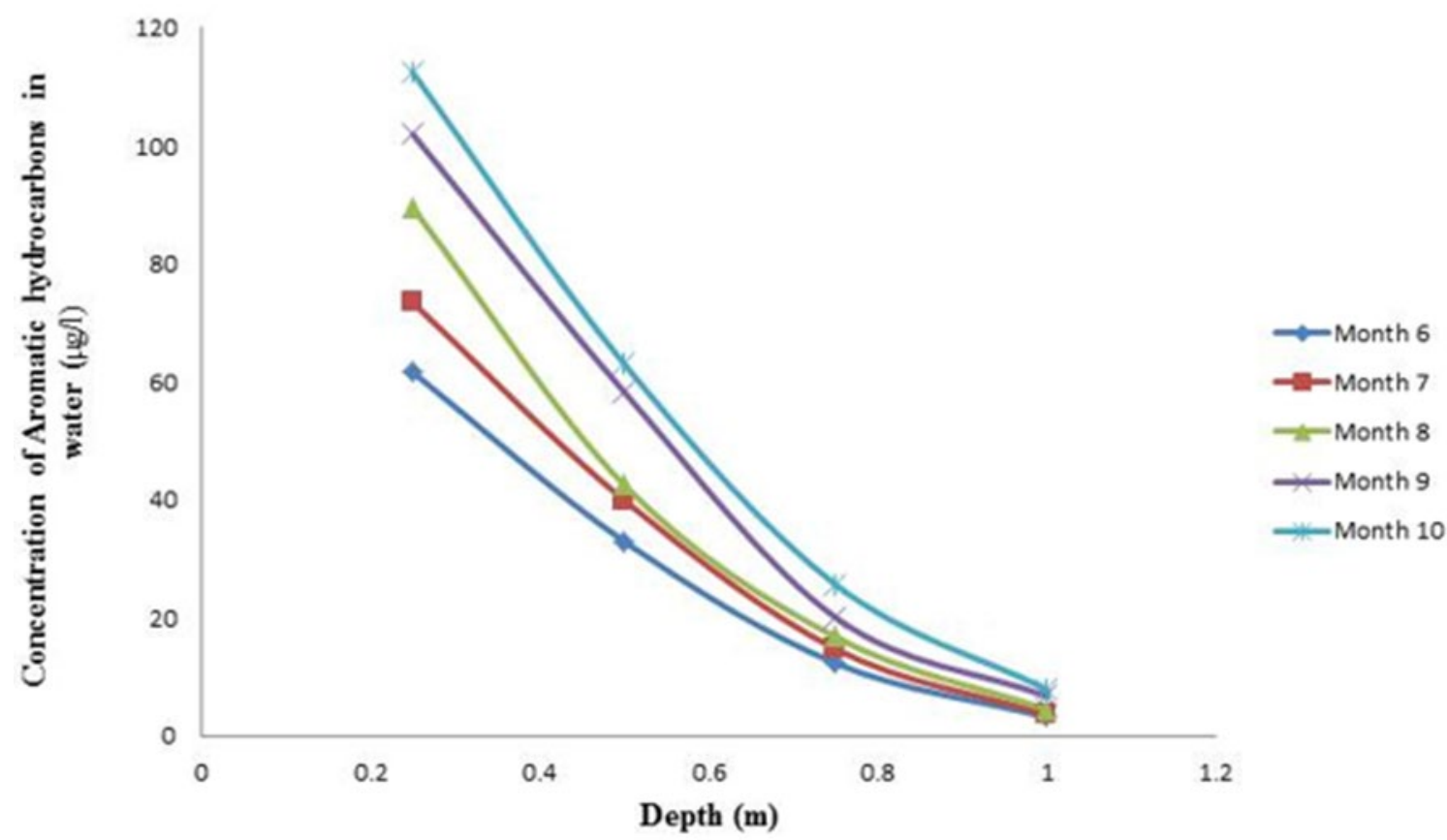

Figure 8. Concentration of aromatic hydrocarbons versus depth in water for month 6-10

observable build-up of aromatic hydrocarbon concentration at depth of $0.25 \mathrm{~m}$ which is the closest depth strata to the source. However, the dissolution rate compared with that of the aliphatic within depth of $0.25 \mathrm{~m}$ seems relatively low (12.988 $\mu \mathrm{g} / \mathrm{l}, 21.152 \mu \mathrm{g} / \mathrm{l}, 32.913 \mu \mathrm{g} / \mathrm{l}, 41.645 \mu \mathrm{g} / \mathrm{l}, 48.980 \mu \mathrm{g} / \mathrm{l}$, $61.624 \mu \mathrm{g} / \mathrm{l}, \quad 73.399 \mu \mathrm{g} / \mathrm{l}, \quad 89.446 \mu \mathrm{g} / \mathrm{l}, \quad 101.918 \mu \mathrm{g} / \mathrm{l}$ and $112.354 \mu \mathrm{g} / \mathrm{l})$ from the first to tenth month of study. This dissolution rate may be due partly to the relative availability of aromatic hydrocarbon (relative abundance) in the original spilled oil sample $\left(38,380 \mathrm{mg} / \mathrm{m}^{3}\right)$ compared to $538,380 \mathrm{mg} / \mathrm{m}^{3}$ for aliphatics and the ease of dissolution controlled by the coefficient of dissolution as well as the hydrophilic nature of the aromatics. These three factors will determine to a large extent the amount of aromatics available for diffusive transport down the column of water.

At subsequent depths of $0.5 \mathrm{~m}$ to $1.0 \mathrm{~m}$, there is appreciable build-up of aromatic hydrocarbon. This suggests that for high residence time provided for by the absence of convective flow or turbulence, there is the possibility of aromatic downward diffusion downwards the bed of the water. Transport by diffusion led to the presence of aromatic hydrocarbons down to depth of $1.0 \mathrm{~m}$ and most likely below. This is of serious concern because aromatic hydrocarbon availability in water body poses a serious danger to the life therein and thus the entire interdependencies or life chain because of their serious health threats. However, it is to be noted that the concentration of aromatic hydrocarbon is here observed to be 


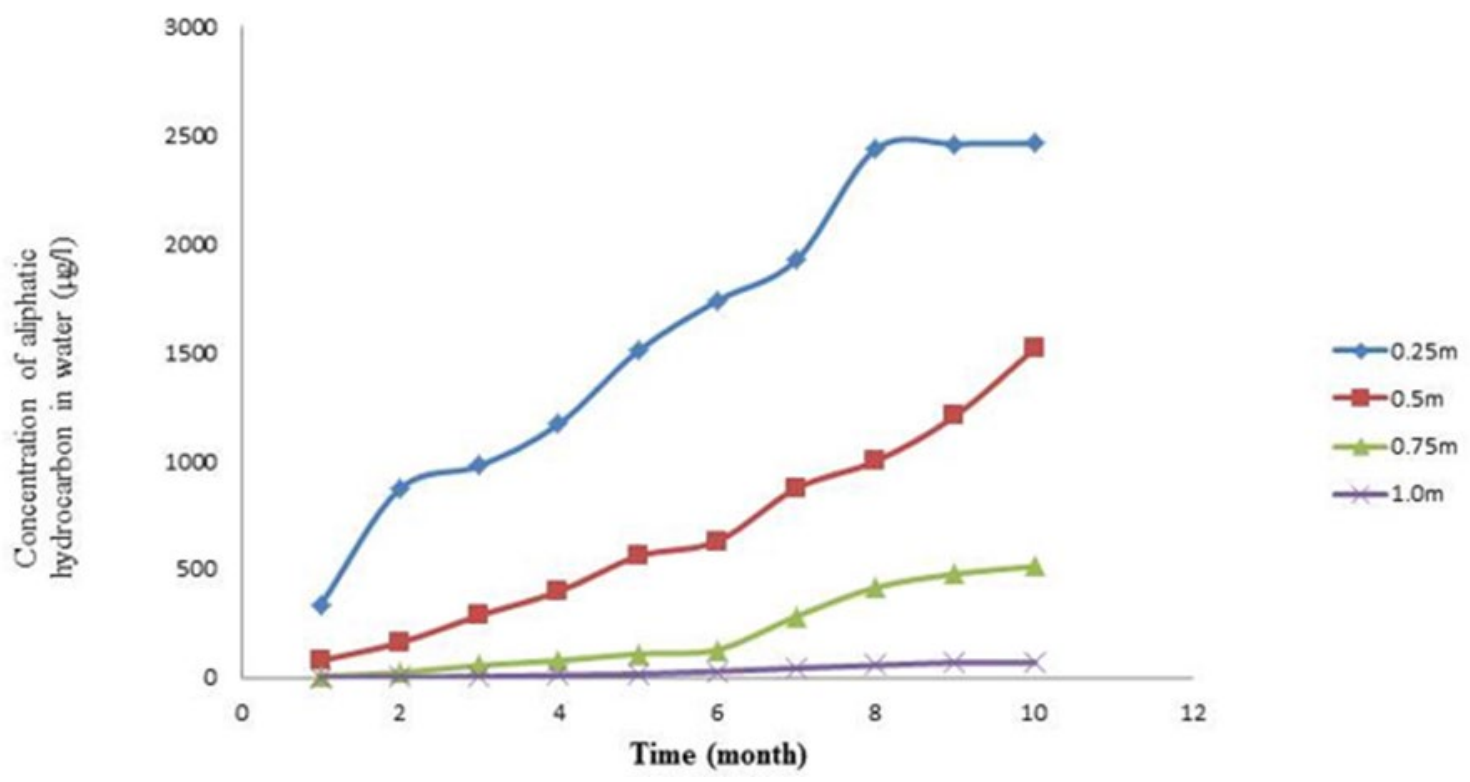

Figure 9. Concentration of aliphatic hydrocarbons versus time

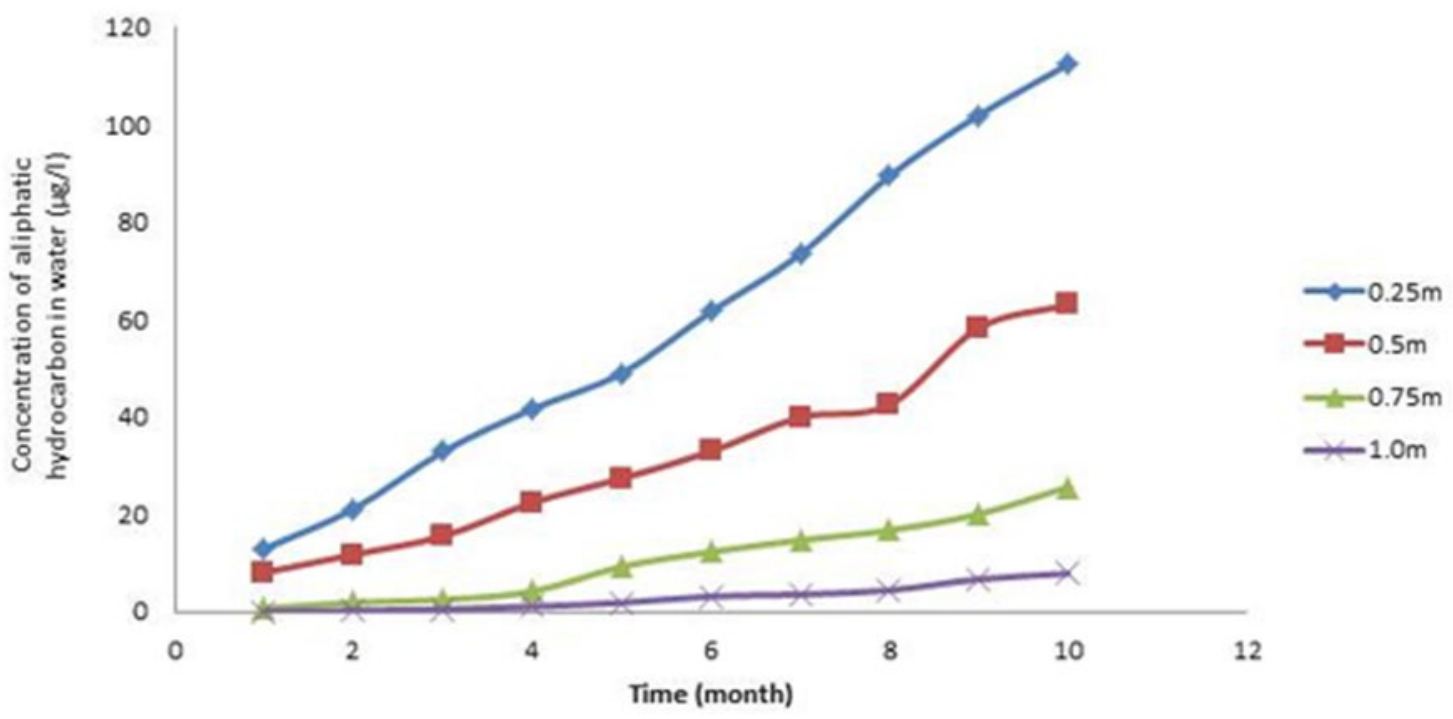

Figure 10. Concentration of aromatic hydrocarbons versus time

somehow lower than for aliphatic hydrocarbon as against the hydrophilic nature of aromatics reported by Brewer et al. (2013) and Massachusetts Department of Environmental Protection (MADEP) (2002b). This could likely be attributed to the low availability of aromatics compared to the aliphatics that are almost fifteen times more in concentration.

Figure 9 highlights the aliphatic hydrocarbon concentration with time at a fixed depth along the water column.

Figure 9 shows that with increasing time at a fixed depth, there is aliphatic hydrocarbon accumulation at each depth strata due to the concentration gradient between the source (preceding strata) and the water body (present strata). A possible reason for this is could be the continuous release (dissolution) of hydrocarbon components from the top surface and as mentioned above, fresh water seems to support the transport of aliphatic hydrocarbons through water column. It therefore suggests that with time and until equilibrium is attained at a particular depth, there may be a continuous accumulation across the depths of the water column with attendant increase in hydrocarbon risk level. The values of concentration at depth of $0.25 \mathrm{~m}$ for month one to month ten respectively show a high level accumulation rate $-355.758 \mu \mathrm{g} / \mathrm{l}$, $870.250 \mu \mathrm{g} / \mathrm{l}, \quad 976.351 \mu \mathrm{g} / \mathrm{l}, \quad 1168.450 \mu \mathrm{g} / \mathrm{l}, \quad 1505.365 \mu \mathrm{g} / \mathrm{l}$, $1737.565 \mu \mathrm{g} / \mathrm{l}, 1927.250 \mu \mathrm{g} / \mathrm{l}, 2437.970 \mu \mathrm{g} / \mathrm{l}, 2461.620 \mu \mathrm{g} / \mathrm{l}$ and $2462.690 \mu \mathrm{g} / \mathrm{l}$. This trend is replicated at all other depths which implies that over a relatively long period, there is the possibility of aliphatic hydrocarbon accumulation at the $0.25 \mathrm{~m}$ region which surely will lead to subsequent downward transport thus resulting in accumulation across and down to the bed of the water body thereby increasing the risk level as the resultant concentrations have been seen to surpass the permissible limit.

Figure 10 highlights the aromatic hydrocarbon concentration at a fixed depth along the water column.

Figure 10 shows that with time as observed for aliphatic hydrocarbon transport profile above, there will also be a gradual increase in aromatic hydrocarbon concentration from 
month to month at fixed depth. From months one to ten at fixed depth of $0.25 \mathrm{~m}$, the aromatic hydrocarbon concentration gave $12.988 \mu \mathrm{g} / \mathrm{l}, \quad 21.152 \mu \mathrm{g} / \mathrm{l}, \quad 32.913 \mu \mathrm{g} / \mathrm{l}, \quad 41.645 \mu \mathrm{g} / \mathrm{l}$, $48.980 \mu \mathrm{g} / \mathrm{l}, 61.624 \mu \mathrm{g} / \mathrm{l}, 73.399 \mu \mathrm{g} / \mathrm{l}, 89.446 \mu \mathrm{g} / \mathrm{l}, 101.918 \mu \mathrm{g} / \mathrm{l}$ and $112.354 \mu \mathrm{g} / \mathrm{l}$. While at $1.0 \mathrm{~m}, 0.081 \mu \mathrm{g} / \mathrm{l}, 0.301 \mu \mathrm{g} / \mathrm{l}$, $0.532 \mu \mathrm{g} / \mathrm{l}, 1.109 \mu \mathrm{g} / \mathrm{l}, 1.890 \mu \mathrm{g} / \mathrm{l}, 3.211 \mu \mathrm{g} / \mathrm{l}, 3.587 \mu \mathrm{g} / \mathrm{l}, 4.460 \mu \mathrm{g} / \mathrm{l}$, $6.726 \mu \mathrm{g} / \mathrm{l}$ and $7.901 \mu \mathrm{g} / \mathrm{l}$ were recorded. The result also shows a trend of positive rate of accumulation that even at low depths of $1 \mathrm{~m}$, the positive accumulation is also very evident to a level far beyond the permissible limit. This also suggest that for fresh water, the transport of aromatic hydrocarbon through diffusion is significant and shows the level of threat that an oil spill left for a while and not attended to in a mangrove swamp could pose to the environment.

\section{CONCLUSION}

The Niger Delta region of Nigeria has among others, static water bodies with oil facilities and operations. With the prevalence of oil spill, there is an urgent need for adequate study of the fate of oil spill in this unique mangrove area so as to develop a quick response guide and contingency pathway based on adequate information and understanding of the implication of delay and possible neglect. This study has brought to the fore the implication of delay and the pattern of transport of spilled oil components in relatively static water. It has shown that both aliphatic and aromatic hydrocarbon components can migrate from the oil bulk into water column thus making effective cleanup operation almost impossible and constituting serious and long term danger to the aquatic life and entire value chain.

\section{REFERENCES}

Abowei, M. F. N. (1996). Prediction and consequences of petroleum spills into the Nigerian aquatic environment in the year 2000. International Journal of Environment and Pollution, 6(23), 306-321.

Adebanwi, W. (2001). Nigeria: shell of a state. Third World Traveller. Available at: http://www.thirdworldtraveler.com /Africa/Nigeria_Shell_State.html

Akpofure, E. A., Efere, M. L. and Ayawei, P. (2000). Oil spillage in Nigeria's Niger Delta; Integrated grass-root post impact assessment of acute damaging effects of continuous oil spills in the Niger Delta, Urhobo historical Society. Available at: www.waado.org/Environment/PetrolPolution/OilSpills/Oil SpillsImpact

American Society for Testing and Materials (ASTM) (1982). Methodology for comparison of Petroleum oil by oil and gas chromatography. ASTM Method D 3328-78.

Badejo, O. T. and Nwilo, P. C. (2005). Management of oil spill dispersed along the Nigerian Coastal areas. http://hdl.handle.net/1834/267
Bragg, J. R. and Owen, E. H. (1995). Shoreline cleansing by interactions between oil and fine mineral particles. Proceedings of 1995 international oil spill Conference, Washington D.C., pp. 219-227. https://doi.org/10.7901/2169-3358-1995-1-219

Brewer, R., Nagashima, J., Kelley, M., Heskett, M. and Rigby, M. (2013). Risk-based evaluation of total petroleum hydrocarbons in vapor intrusion studies. International Journal of Environmental Research and Public Health, 10(6), 2441-2467. https://doi.org/10.3390/ijerph10062441

Chapman, P. M. and Fink, R. (1984). Effects of Puget Sound Sediments and their elutriates on life cycle of Capitella Capitata. Bulletin of Environmental Contaminants Toxicology, 33, 451-459. https://doi.org/10.1007/ BF01625569

Egberongbe, F. A. O, Nwilo, P. C. and Badejo, O. T. (2006). Oil Spill Disaster Monitoring Along Nigerian Coastline. 5th FIG Regional Conference Accra, Ghana, March 8-11, pp. 3-4.

Federal Ministry of Environment, Abuja, Nigeria Conservation Foundation, Lagos. WWF UK, CEESP- IUCN Commission on Environmental, Economic, and Social Policy, Niger Delta Natural Resource Damage Assessment and Restoration Project' Phase 1 - Scoping Report, May 31, 2006. pp. 18-21.

Gundlach, E. R. (1987). Oil-holding capacities and removal coefficients for different shoreline types to computer simulate spills in coastal waters. Proceedings of the 1987 International Oil Spill Conference, pp. 451-457. https://doi.org/10.7901/2169-3358-1987-1-451

Imanian, H., Kolahdoozan, M. and Zarrati, A. R. (2017). Vertical dispersion in oil spill fate and transport models. Journal of hydrosciences and environment, 1(2), 21-33.

Le Floch, S., Guyomarch, J., Merlin, F. X, Stoffyn-Egli, P., Dixon, J. and Lee, K. (2002). The influence of salinity on oilmineral aggregate formation. Spill Science and Technology Bulletin, 8(1), 65-71. https://doi.org/10.1016/S13532561(02)00124-X

Lerche, I. and Petersen, K. (1995). Salt and sediment dynamics. USA: CRC Press.

Martin Marietta Materials (2007). Materials safety data sheet. Martin Marietta.

Massachusetts Department of Environmental Protection (MADEP) (2002b). Indoor Air Sampling and Evaluation Guide, WSC Policy No. 02-430. Commonwealth of Massachusetts, Boston, MA. Available at: https://www.mass.gov/doc/wsc-02-430-indoor-airsampling-and-evaluation-guide-0/download

Ndimele, P. E., Saba, A. O., Ojo, D. O. and Ndimele, C. C. (2018). Remediation of crude oil spill. In The political ecology of oil and gas activities in Nigerian aquatic ecosystem, pp. 369-384. Academic Press. https://doi.org/10.1016/ B978-0-12-809399-3.00024-0

Njobuenwu, D. O. (2014). Modeling spreading rate force of petroleum spill on placid aquatic medium. Journal of Science and technology research, 23(3), 48-52. 
Njobuenwu, D. O., Amadi, S. A. and Dagda, K. K. (2005). Marine oil spill: Contingency planning, Response and clean-up strategies. International Journal of Science and Technology, 2(4), 36-43.

Owens, E. H. and Lee, K. (2003). Interaction of oil and mineral fines on shorelines: Review and assessment. Marine Pollution Bulletin, 47(9-112), 397-405. https://doi.org/ 10.1016/S0025-326X(03)00209-1

Owens, E. H., Reimer, P. D., Lamarche, A., Marchant, S. D. and O’Brien, D. K. (2003). Pre-Spill shoreline mapping in Prince William Sound, Alaska. In Proceedings of the twenty-sixth Artic and marine oil spill program (AMOP) Technical Seminar, Victoria, British Columbia, Ottawa, ON, Canada, Canada Environment, June 10-12, pp. 233-251.
Page, C. A., Bonner, J. S., Sumner, P. L., McDonald, T. J., Autenrieth, R. L. and Fuller, C. B. (2000). Behaviour of chemically-dispersed oil and a whole oil on a near-shore environment. Water Research, 34, 2507-2516. https://doi.org/10.1016/S0043-1354(99)00398-X

Parent, R. (2017). Available at: www.experts.com/crudeoil

US Environmental Protection Agency. (2004). Extraction and analysis for polycyclic aromatic hydrocarbons by gas chromatography, Method 8270 US EPA 8270 for the US Environmental Protection Agency, Washington, D.C.

Xie, W.-H., Shiu, W.-Y. and Mackay, D. (1997). A review of the effect of salts on the solubility of organic water. Marine Environmental Research, 44(4), 429-444. https://doi.org/10.1016/S0141-1136(97)00017-2 